\title{
THE COMPETITIVENESS ANALYSIS OF COCOA COMMODITY IN THE DISTRICT OF SIGI
}

\author{
Andika Ibrahim ${ }^{1)}$, Marhawati Mappatoba ${ }^{2)}$, Yulianti Kalaba $^{2)}$ \\ ${ }^{1)}$ Student of Agribusiness Faculty of Agriculture. University of Tadulako. Palu. \\ ${ }^{2)}$ Lecturer and Researcher at Department of Agribusiness Faculty of Agriculture. University of Tadulako. Palu.
}

\begin{abstract}
This study aims to determine the competitiveness of cocoa commodity in the district of Sigi and the impact of government policies by analyzing the effects of cocoa price changes, cocoa's input price and cocoa production to the competitiveness of cocoa. Data collection is done in Sub-district of Palolo with the number of respondents 31 farmers and also data supported by data from other related agencies. The research objective answered by using analytical tools Policy Analysis Matrix (PAM). Results of the study found that cocoa in Sigi District has comparative and competitive advantages with the value of Domestic Cost Ratio (DCR) and the Private Cost Ratio (PCR) i.e. 0.45 and 0.50. Results for Nominal Protection coefficient of output value (NPCO) is 0.88 and Nominal Protection Coeffisients of Input (NPCI) is 0.80 respectively show the government's policies are protective for cocoa farmers in the district, while the EPC value is 0.89 indicates the policy is inhibiting the production of farmers with effect of ratio 0.09 . The sensitivity analysis of changes in production, the price of cocoa bean and Subsidized- fertilizer prices, shows that the change in production is an indicator that most influence the competitiveness of cocoa in Sigi District.
\end{abstract}

Key Words : Cocoa, competitiveness, governments policy, policy analysis matrix.

\section{INTRODUCTION}

Indonesian agricultural sector plays a great not only for the country itself, but Indonesian agricultural sector is also has quite important role in the world market, a wide range of Indonesia's main commodities such as palm oil, tea, coffee, cocoa, rubber became Indonesia's export commodities that superior in the world market. Cocoa is one of Indonesia's commodity where in the global market Indonesia as the third largest country as cocoa producer in the world after Evory Coast (Cote d'Ivoire) and Ghana and in Asian countries Indonesia is the largest producer. Total production of Indonesia had reached 775.500 tons of cocoa beans (Food and Agriculture Organization, or FAO, 2013).

Based onentire recent data from Indonesia's cocoa production, the production of cocoa can be seen decreased compared to production data from 2003 to 2006, which showed increased production. There are many factors that can affect the production of cocoa ranging from less developed cultivation technology optimally use the random seed seedlings, old age plants, pests and diseases, climate change and factor prices often fluctuate. In addition, low productivity is also due to the production of cocoa beans which 90 percent comes from small farmers who do not understand the concept of good cocoa crop cultivation, so the yields are sometimes not maximized (Asrul, 2013).

While the world cocoa production declining, cocoa prices actually rise up from time to time, it is because the increase in raw material requirement grinding cocoa beans in Europe and North America were up about 4.7 per cent and 8.3 per cent in line with the global cocoa production 
instead it continues to decrease, causing a limited supply of cocoa beans, so the price at that time rose to its highest level in October around $£ 1,771$ per ton and $U$ \$ 2,769 per ton in New York. (ICCO, 2016).

Number of Indonesian cocoa production each year fluctuates with total cocoa production of Indonesia is dominated by the production of the province of South Sulawesi and Central Sulawesi (BPS, 2015). Central Sulawesi is known as cocoa production centers for Indonesian state, therefore, it is appropriate to have research about the condition of Indonesian cocoa done in the province. Central Sulawesi alone has 12 districts and one city that the whole region has cocoa. Sigi is one of the central areas of cocoa production that has above average production of other districts. Sigi regency own productivity based on BPS Sulawesi is above average compared with other districts. In addition to that, some sources also stated that the cocoa beans from Sigi district has the most excellent quality of other districts in Central Sulawesi. Proved that for the manufacture of chocolate on chocolate house of Central Sulawesi, the raw materials are often derived from Palolo Sigi because some farmers in the area have been given intensive price to make the fermented cocoa production process prior to further use by chocolate house cocoa production.

The high Production of cocoa central Sulawesi coupled with improved market opportunities are expected to bring prosperity to the cocoa farmers in particular to the farmers in Sigi. But as these opportunities are generally about cocoa Indonesia, it is also facing many problems such as the low-price export because the quality is not support, the quality of the result from a variety of pests as well as the drying process of unfermented-cocoa beans. The selling price of cocoa is also very important bearing on the productivity of cocoa Indonesia, especially for smallholders, but not all of the price received by farmers is the price that corresponds to the actual market price, due to market failures. Such failures can be seen from the comparison of the input and ouput prices that cocoa farmers received, price is actually prevailing in the market. As a simple example is the price of cocoa beans received by farmers is not determined by the changes in supply and demand of the world cocoa. If the world price of cocoa has increased from the normal price due to limited supply of worldscocoa beans. The received priceby farmers may also increase and benefit for farmers. But in the process of trading, prices of cocoa is more likely to be determined by the traders, intermediaries and large companies that control the price of cocoa beans.

The tendency of increasing the level of consumption of cocoa and cocoa prices on the world is a great opportunity for Indonesia especially those for cocoa farmers in the district of Sigi to improve and guarantee the continuity of the amount of cocoa production. Through some of these opportunities, increasing productivity needs to be reviewed from various aspects that can affect the competitiveness of cocoa. Various obstacles and opportunities are discussed in the background of the research is the subject that is important to be used as guidelines for analyzing the competitiveness of the commodity as well as analysis in the face of high level of competition in the international market with a market share of cocoa growing from time to time.

\section{RESEARCH METODOLOGY}

Place and Time. Research conducted at Palolo Sub-district of Sigi District. Location research done deliberately (pusposive) with consideration that Palolo Sub-district has the highest cocoa production as compared to other sub-districts in Sigi Districtthat makes the cocoa as one of the commodity area. 
Table 1. Policy Analysis Matrix (PAM)

\begin{tabular}{lcccc}
\hline & \multirow{2}{*}{ Revenue } & \multicolumn{2}{c}{ Input Cost } & \multirow{2}{*}{ Profit } \\
\cline { 3 - 4 } & & Tradeable & Domestic & \\
\hline Private & $\mathrm{A}$ & $\mathrm{B}$ & $\mathrm{C}$ & $\mathrm{D}$ \\
Social & $\mathrm{E}$ & $\mathrm{F}$ & $\mathrm{G}$ & $\mathrm{H}$ \\
Divergences & $\mathrm{I}$ & $\mathrm{J}$ & $\mathrm{K}$ & $\mathrm{L}$ \\
\hline
\end{tabular}

Source: Monke and Pearson, 1989.

Respondent Determination. Central Sulawesi is the center of the province that produces most of the cocoa beans in Sulawesi Island. From the entire district, Sigi District selectedas well a Palolo Sub-district and Makmur Village as the Capital of Sub-district. From the selected location village, 31 respondents of cocoa farmers were selected by using simple random sampling technique with consideration that the cocoa farmers are homogeneous population.

Analysis of Data. To analyze the competitiveness of cocoa the research using the methods of Policy Analysis Matrix (PAM) Monke and Pearson (1989), the use of PAM is intended to determine the economic efficiency and incentives from government intervention, and its impact on farming activities. In the model PAM revenues, expenses and profits are distinguished by price private (market) and the social price. The second difference in price is the impact of measures taken by the government, as well as distortions in the market input and / or output. Private prices for cocoa is the price level that would be acceptable to cocoa farmers, based on the auction price, while the price of social derives from the imports price (fob) at the nearest port, plus the cost of freight and insurance as well as loading and unloading at the port and freight to PG. (Ariani et al, 2004).

In (Policy Analysis Matrix) PAM, revenues, expenses and profits is classified by prices of private and social prices. Private prices is the price actually received by producers. While price is the price prevailing social if the market is in a state of perfect competition. The difference between the private social prices is the number of transfers that is used to measure the impact of government policies (Wahyudi, 1989).

The shadow price is the price that is happening in the economy in a state of perfect competition in equilibrium (Gettinger 1982). Shadow price should be known in advance to be able to know the social price required in PAM analysis tables. The prevailing market price in one period of time can not be used directly in an economic analysis because the price is often at variance with the opportunity costs of social or opportunity cost and can be changed at any time, so as to obtain a value close to the opportunity costs of social or shadow prices, needs to be done adjustments in advance of the prevailing market price. Shadow exchange rate can be obtained using the following equation:

$$
\text { SERt }=\text { OERt } / \mathrm{SCF}
$$

The standard conversion factor can be obtained by the equation:

$$
\mathrm{SCFt}=\frac{\mathrm{Xt}+\mathrm{Mt}}{(\mathrm{Xt}-\mathrm{TXt})+(\mathrm{Mt}+\mathrm{TMt})}
$$

Where :

SERt $=$ Shadow Exchange Rate in the year of $\mathrm{t}(\mathrm{Rp} /$ S US)

$\mathrm{SCFt}=$ Standart coversion factorin year of $\mathrm{t}$

OERt = Official Exchange Rate

$\mathrm{Xt}=$ Export Value of Indonesia in the year of $\mathrm{t}(\mathrm{Rp})$

Mt = Import Value Indonesia in the year of $t(R p)$

$\mathrm{TMt}=$ Import tax andImport Duty in the year of $t(R p)$ 
Values in each cell in the PAM matrix above for cocoa farming calculated in the period of the production cycle. From these data, futhervarious analyze indicators as follows:

1. Analysis of Comparative and Competitiveness

a. Domestic Resource Cost Ratio : DRCR $=\mathrm{G} /(\mathrm{E}-\mathrm{F})$

DRCR is an indicator that shows the number of comparative advantage of domestic resources that can be saved to produce one unit of foreign exchange. The system has a comparative advantage, if DRCR <1. The smaller the DRCR, means more efficient and higher its competitiveness.

b. comparative advantage. Private Cost Ratio $:$ PCR $=\mathrm{C} /(\mathrm{A}-\mathrm{B})$

PCR is an indicator of private profitability which demonstrates the ability of the system to pay for domestic costs and remain competitive. The system is competitive if PCR $<1$. The smaller the value of PCR, means more competitive.

2. The Impact of Government Policy

a. Output Policy

Nominal protection Coefficient on Output: $\mathrm{NPCO}=\mathrm{A} / \mathrm{E}$

NPCO is the level of government protection towards the domestic output. Policy is protective for output, if the value NPCO $>1$. The larger the value NPCO, meaning the higher the level of government protection for the output.

b. Input Policy

Nominal protection Coefficient on Tradable Input $: \mathrm{NPCI}=\mathrm{B} / \mathrm{F}$

NPCI is an indicator that shows the level of government protection towards the domestic input prices. If the value of NPCI $<1$, meaning there is a policy that is protective for tradable inputs.

c. Input dan Output Policy Effective Protection Coefficient: $\mathrm{EPC}=$ (A-B)/(E-F)
EPC is an indicator showing the degree of protection against the simultaneous output and tradable inputs. Policies are still protective, if the value of EPC> 1. The larger the value of the EPC, meaning the higher the level of government protection for domestic commodities.

Subsidi ration percentage (SRP): $L / E$ or $(D-H) / E$

SRP is the percentage ratio between the net transfer to social acceptance $(\mathrm{L} / \mathrm{E})$. This ratio shows the proportion of transfer to the output value of government policy or the addition/subtraction acceptance for their policies.

The sensitivity analysis aims to look at how changes in factor productivity, the price of cocoa prices and other inputs to the competitiveness of cocoa Sigi. According Kadariah (1988), the sensitivity analysis conducted by: (1) Changing the size of the factors that are important, each separately or several in combination with a percentage of determining a sensitivity of the results of calculations on these changes, (2) Determining how much factor is changed so that the results of calculations made project can not be accepted.

3. Analisisof Sensitivity

The sensitivity analysis is conducted to answer the third research question. This analysis was also done for the previous method of the Policy Analysis Matrix only impose a price level whereas in the real situation prevailing price levels for input and output is varied. Therefore, the sensitivity analysis is important to do.

\section{RESULT AND DISCUSSION}

Overview of The Location Research. Sigi District is a region that splitted from Donggala District which at that time became the largest cocoa producing areas in Central Sulawesi. After the split Sigi still one of the district with cocoa 
production above the average from other districts. While Palolo Sub-districtis the central production cocoa plantations in Sigi selected as a study site. Geographically District of Palolo is a division of the District Sigi Biromaru is located exactly in the north and in the south by Nokilalaki district of the District Sigi bordering to Biromaru and on the east by the District Parigi Moutong. Palolo subdistrict is geographically located between 0058'53 " - 1014'31 " LS and 119057"46" 120021'26 " BT. Overall Palolo subdistrict area is $629.09 \mathrm{~km} 2$ with a percentage of 12.05 percent of Sigi. This district has 22 villages and Makmur Village as the capital of the district. While the village is the largest in area Prosperous village with an area of $123.87 \mathrm{~km} 2$, approximately 19 percent of the total acreage in the District Palolo. Every village in the district Palolo has had government agencies like LPMD, the BPD and the PKK. The village also has a village security personnel Hansip as many as 170 people.

Palolo sub-district consists of 60 villages and $176 \mathrm{RT}$. The number of hamlets and RT are most numerous in the village hamlet Lembantongoa ie 5 and 14 RT. Average number of hamlets and RT are at least as many as 2 Sarumana village hamlets and 4 RT. Based on the statistical data has some potential Palolo District of commodities in the regions. According to agricultural census data District of Palolo that cocoa is a commodity with a presentation of the first order number as many as 5,393 peasant farmer population, followed by Commodity Rice as many as 2,013 farmers and 844 farmers of corn, pecan807 and 266 avocado growers and farmers.

Private and Social Cost Calculation Input-output Table. Is the relationship between the ratio of the number of inputs used that are used with the amount of production output. The value obtained is the result of the calculation of the data from 31 respondents averaged first and then converted so as to get the number of units/ha/year.

Table 2 is the recapitulation of respondents drawn from the study site Palolo Sub-District. While the ouput of cocoa beans Obtained from cocoa of Sigi District in 2015 with a total production area of $17156.00 \mathrm{~kg}$ and 27680 .

Private Price. Is the real prices received by farmerswhich data obtained from the survey of the location and retrieval of data from respondents. Real prices obtained are also matched to some of the price difference in farm shop and also based on price data from the UPT plantation in Subdistrict Palolo.

Social Price. The approach to the shadow price of cocoa output is determined based on the border (border price) is the price f.o.b (Free on Board) because cocoa is a commodity that is oriented to export activities. F.o.b prices are export prices in the exporting country. Approach the shadow price of output at the producer level for the export market orientation using export parity price (Pearce and Nash 1981).

In Table 3 it can be seen that the price is very varied between fertilizer one with another, between one and another pesticide. The price of cocoa in the study actually also very diverse and vary depending on the quality of seeds produced, but if taken as a whole, the above price is the price generally accepted cocoa farmers in Sigi.

Table 4 shows the data of the final cocoa prices after deducting the expenses of Rp trading system. 41057.44, -. Price c.i.f cocoa price data obtained today by the World Cocoa Organization (ICCO), which uses a price based on the US dollar. Fertilizers used in cocoa farming are urea, TSP and KCL. Source f.o.b and c.i.f fertilizer prices using the price based on the price of social World Bank Commodities Price Data (the pink sheet) 2015. 
Table 2. Data of Physical Input-Output Cocoa Farmingin the District of Sigi 2015

\begin{tabular}{llr}
\hline \multicolumn{1}{c}{ Input-output (ha) } & \multicolumn{1}{c}{ Inputs } & Count \\
\hline Tradable Input & a. Fertilizer & \\
& Urea (kg/ha) & 195,0 \\
SP-36 (kg/ha) & 97,5 \\
KCL (kg/ha) & 97,5 \\
& b. Pest and desease control & \\
& Gramoxone (ltr/ha) & 4,9 \\
& Dithan M.45 (ltr/ha) & 9,7 \\
& Klormid (ltr/ha) & 9,7 \\
a. Labor (HOK) & 7,8 \\
Domestic Factors & Fertilizing & 11,7 \\
& Spraying & 11,7 \\
& Maintenance & 46,8 \\
& harvest & 5,8 \\
& Post-harvest & 1,0 \\
& b. Land Tax (ha) & 853,9 \\
& c. Kakao Seed (pohon) & 23,0 \\
d. Depreciation(Unit) & 620 \\
\hline
\end{tabular}

Source: Primer Data After Processed, 2015.

Table 3. Private and Social Price Input-output Cocoa Farming in the District of Sigi 2015

\begin{tabular}{clcr}
\hline Input-output & \multicolumn{1}{c}{ Inputs } & Private Price (Rp) & Social Price (Rp) \\
\hline Input tradable & a. Fertilizer & & \\
& Urea (kg/ha) & 1.840 & 3.293 \\
& SP-36 (kg/ha) & 1.760 & 5.471 \\
& KCL (kg/ha) & 3.680 & 4.389 \\
& b. Pest and desease control & & \\
& Gramoxone (ltr/ha) & 55.000 & 44.000 \\
& Dithan M.45 (ltr/ha) & 100.000 & 80.000 \\
& Klormid (ltr/ha) & 130.000 & 104.000 \\
Domestic Factors & & \\
& a. Labor (HOK) & 50.000 & 50.000 \\
& Fertilizing & 50.000 & 50.000 \\
& Spraying & 50.000 & 50.000 \\
& Maintenance & 50.000 & 50.000 \\
& harvest & 50.000 & 50.000 \\
& Post-harvest & 20.000 & 20.000 \\
& b. Land Tax (ha) & 6.000 & 6.000 \\
c. Kakao Seed (pohon) & 34 & 34 \\
Output & d. Depreciation(Unit) & 36.000 & 40.938 \\
\hline
\end{tabular}

Source: Primer Data After Processed, 2015.

Pesticides used for cocoa farming of various kinds, ranging from insecticides, herbicides and fungicides. The shadow price is assumed to be private prices according to research conducted by Anapu et al, (2003), Hardware gardens used farm cocoa consists of a hand sprayer, scissor cuttings, scissors branches, knife trim, saws crop, reaping knives, knife wiwil, and buckets and sacks. The processing equipment consists of spades, winnowing, and sieve the sorting. Price shade garden equipment and the processing is the same as its market price, assuming no government policies that intervene in production and trade of these tools directly to the market 
price of that happening is very small and approaching perfect competition and assumed to heve the same price.

According to Malian et al, 2004, in Andala et al, 2014 set the shadow price of labor is equal to the price prevailing private. The social price is the price of efficiency or cost of goods in the international market which to measure the true social opportunity cost which can be obtained by farmers. Social input prices obtained by price price border or border price. Social prices for fertilizer inputs and medicines using border price for which accounts have been written in the part before the table above. Each input is calculated price and the various factors that influence to obtain price as in the table above, for labor and seedlings used the same price for the whole input only from local resources and assumed the price has not changed for the price factor.

\section{Competitiveness \\ Analysis \\ and \\ Government Policy's Impact to Cocoa in The District of Sigi. Analysis of}

competitiveness and government policies can be analyzed using PAM matrix by multiplying the data analysis of private budget and social budget obtained through calculation tables private and social rates with data on production and land area in Sigi.

Table 5 shows the results of calculation of input costs and output in the business of cocoa in Sigi. Simply PAM consists of data on revenues and costs. Costs consist of tradable inputs and domestic input or non-tradable and to earn sufficient profits simply by subtracting between the reception and the two charges on the table. Results from the next table can be used to analyze the degree of cocoa farming profits both from the private and social price level as well as analyzing the impact of government policies in terms of both input and output means of production, as for the results of further analysis of the impact of government policy can be seen in the following table:

Table 4. Sosial Price of Inputs 2015

\begin{tabular}{|c|c|c|c|c|c|}
\hline No. & Uraian & Kakao & Urea & TSP & $\mathrm{KCL}$ \\
\hline 1. & C.i.f/F.o.b (\$/ton) & $3.063,76$ & 272,92 & 385,00 & 302,93 \\
\hline 2. & Pengapalan \& Asuransi (\$/ton) & 17,5 & 28,6 & 93,0 & 93,0 \\
\hline 3. & C.i.f/F.o.b Indonesia (\$/ton) & $3.046,26$ & 244,32 & 478,0 & 395,93 \\
\hline 4. & Nilai tukar $(\mathrm{Rp} / \$)$ & 13.852 & 13.834 & 13.834 & 13.834 \\
\hline 5. & Premium nilai tukar (\%) & $0 \%$ & 0 & 0 & 0 \\
\hline 6. & Nilai tukar equlibrium $(\mathrm{Rp} / \$)$ & 13.891 & 13.834 & 13.834 & 13.834 \\
\hline 7. & $\begin{array}{l}\text { C.i.f Indonesia dlm mata uang } \\
\text { domestik (Rp/ton) }\end{array}$ & 42.558 .690 & $\begin{array}{r}3.379 .922,8 \\
8\end{array}$ & $6.612 .652,00$ & $5.477 .295,62$ \\
\hline 8. & Faktor konversi berat (ton-kg) & 1.000 & 1.000 & 1.000 & 1.000 \\
\hline 9. & $\begin{array}{l}\text { C.i.f Indonesia dlm mata uang } \\
\text { domestik (Rp/kg) }\end{array}$ & $42.558,69$ & $3.379,92$ & $6.612,65$ & $5.477,30$ \\
\hline 10. & $\begin{array}{l}\text { Transportasi dan handling ke pasar } \\
\text { pedagang besar }(\mathrm{Rp} / \mathrm{kg})\end{array}$ & 456,75 & 391 & 117 & 117 \\
\hline 11. & Biaya pemasaran & 500 & 83 & 15 & 15 \\
\hline 12. & Nilai Sebelum Pengolahan (Rp/kg) & $43.515,44$ & 2905,92 & $6.744,65$ & $5.609,30$ \\
\hline 13. & Faktor konversi pengolahan & $100 \%$ & $100 \%$ & $100 \%$ & $100 \%$ \\
\hline 14. & $\begin{array}{l}\text { Harga paritas impor tingkat } \\
\text { pedangang besar }(\mathrm{Rp} / \mathrm{kg})\end{array}$ & $43.515,44$ & $2.905,85$ & $6.744,65$ & 5609,30 \\
\hline 15. & $\begin{array}{l}\text { biaya distribusi ke tingkat petani } \\
(\mathrm{Rp} / \mathrm{kg})\end{array}$ & 2.458 & 50 & 20 & 20 \\
\hline 16. & $\begin{array}{l}\text { Harga paritas impor tingkat petani } \\
(\mathrm{Rp} / \mathrm{kg})\end{array}$ & $41.057,44$ & $2.855,92$ & 6742,65 & $5.589,30$ \\
\hline
\end{tabular}

Source: Secondary Data After Processed, 2015. 
Table 5. Matrix of Policy Analysis Cocoa Farmingin the District of Sigi

\begin{tabular}{lcccr}
\hline & \multirow{2}{*}{ Revenue } & \multicolumn{2}{c}{ Input Cost } & \multirow{2}{*}{ Profit } \\
\cline { 3 - 4 } & & Tradable & Domestic & \\
\hline Private & 22.320 .000 & 3.399 .058 & 9.514 .598 & 9.046 .344 \\
Social & 25.455 .929 & 4.266 .905 & 9.514 .598 & 11.674 .426 \\
Divergences & $(3.135 .929)$ & $(867.847)$ & - & $(2.268 .082)$ \\
\hline
\end{tabular}

Sourcer: Primer Data After Processed, 2015.

Table 6. Indicator Assessment of Policy Analysis Matrix (PAM)

\begin{tabular}{clr}
\hline No. & \multicolumn{1}{c}{ Indicator } & Value \\
\hline 1 & Domestic resource cost ratio (DRC) & 0,45 \\
2 & Private Cost Ratio (PCR) & 0,50 \\
3 & Output Transfer (OT) & $(3.135 .929)$ \\
4 & Nominal Protection Coefficient Outputs (NPCO) & 0,88 \\
5 & Input Transfer (TI) & $(867.847)$ \\
6 & Nominal Protection Coefficient Inputs (NPCI) & 0,80 \\
7 & Effective Protection Coeffisient (EPC) & 0,89 \\
8 & Subsidy Ratio Percentage (SRP) & $(0,09)$ \\
\hline
\end{tabular}

Sourcer: Primer Data After Processed, 2015.

Table 7. Against Sensitivity Analysis Cocoa Commodity Competitiveness in Sigi

\begin{tabular}{lrrrr}
\hline & \multicolumn{4}{c}{ Analisis Sensitivitas } \\
\cline { 2 - 5 } \multicolumn{1}{c}{ Indicators } & \multicolumn{1}{c}{$\begin{array}{c}\text { Production } \\
\text { Increase 20\% }\end{array}$} & $\begin{array}{c}\text { Produksi } \\
\text { Decrease 20\% }\end{array}$ & $\begin{array}{c}\text { Cocoa Price } \\
\text { Increase }\end{array}$ & $\begin{array}{c}\text { Fertilizer } \\
\text { Subsidy } \\
\text { Revoked }\end{array}$ \\
\hline PP & 13.870 .344 & 4.942 .344 & 12.542 .304 & 8.538 .497 \\
PCR & 0,41 & 0,66 & 0,43 & 0,53 \\
PS & 16.765 .612 & 6.514 .598 & 11.674 .426 & 11.674 .426 \\
DRC & 0,36 & 0,59 & 0,45 & 0,45 \\
EPC & 0,89 & 0,90 & 1,04 & 0,85 \\
\hline
\end{tabular}

Sourcer: Primer Data After Processed, 2015.

The sensitivity analysis is used to determine how much influence would happen if conditions change in terms of both price and production of the cocoa farming. The amendment is necessary to analyze due to frequent unexpected changes that will not be fixed. So that the results of the analysis will be referenced if the competitiveness of cocoa change when the economy changes occurred from cocoa farming. Some indicators of change such as changes in production of as much as 20 percent as it rose from 620 to $740 \mathrm{~kg}$ or down to $496 \mathrm{~kg}$, as well as changes in the price of private and fertilizer inputs cocoa, below is a table of the results of the analysis of some of the rate of change of the input and output of farm cocoa in Sigi.

Based on Table 7 it can be seen that all changes assumptions of change factors that production is the most influential than changes in fertilizer prices and the price of cocoa. Rated highest competitiveness 0.41 and 0.36 is obtained when production rose by 20 percent, and competitiveness value plummeted 0.66 and 0.59 when production fell 20 percent. The price of cocoa and fertilizer price also affecting but not so big compared to the production. When the subsidy was revoked, a decline in farmers' profits to 
Rp. 8,538,497, -. It is quite influential when assuming the subsidy is revoked and the production of cocoa farmers unchanged.

\section{CONCLUSIONS AND RECOMMENDATIONS}

\section{Conclusions.}

The competitiveness of a commodity is an indication of the success of a region in pursuit of the commodity. The results of this study aimed to analyze the level of success of a region in pursuit of a commodity. The conclusions of the study are as follows:

1. Commodity cocoa in Sigi has comparative and competitive advantages as indicated by the calculation results values of PCR and DRC that are 0.45 and 0.50 .

2. The government's policy is vital to the competitiveness of cocoa and it is protective for cocoa farmers in Sigi. This is shown by NPCO and NPCI value of 0.88 and 0.80 . While the EPC value of 0.89 indicates a policy that is inhibiting the production of farmers with effect ratio of 0.09 .

3. Based on the results of the sensitivity analysis between changes in production, changes in the price of cocoa and the removal of subsidies on fertilizers for farmers. Then change the highest on the competitiveness of cocoa is a change in production, while intensive cocoa prices and removal of subsidies on fertilizers is not so much affect the competitiveness of cocoa.

\section{Recommendations.}

Generally cocoa in Sigi competitiveness comparative, competitive and supported by government policies that are protective for farmers, but there are still enough rate between private costs and social in the farming cocoa, and therefore the recommendation in research are as follows:

1. In general, the competitiveness of cocoa in Sigi has strong competitiveness both comparative and competitive, therefore competitiveness is appropriate to be maintained or even enhanced. Given the many opportunities still available and has not been utilized mainly for the farmers themselves.

2. The government's policy is protective for farmers, especially export restrictions to protect the price of cocoa in the country and prices are subsidized fertilizer, but the indicators are inhibiting policies. That is because the price is protective, but only for large-scale exports to the trader, but prices at the farm level is still low. Similarly, the fertilizer subsidy, but is still limited and the restrictions on the circulation of non-subsidized fertilizer. So it needs special assessment for policy makers in order to fix the existing policies so that the farmer's right on target itself. This is especially true for farmers in Sigi.

3. The results of the sensitivity analysis gives an overview specifically for growers and the government that the factors that affect most on the competitiveness of cocoa is the change in production, so the need for special attention to farmers how production can be further enhanced given that the average productivity in Sigi which was below the optimal and is still likely to be increased.

\section{REFERENCES}

Asrul Laude (2013). Agribisnis Kakao. Edisi Pertama. Jakarta: Media bangsa.

Badan Pusat Statistik (BPS) 2015. Produksi Tanaman Perkebunan Provinsi. Jakarta : BPS.

Food and Agriculture Organization of the United States (FAO). 2013. Crops Production Data Cacao in View Countries. http://faostat3.fao.org.

Gittinger, J.P. 1986. Analisa Ekonomi Proyek-Proyek Pertanian. Edisi Kedua. Universitas Indonesia. Jakarta. 
International Cacao Organization (ICCO). 2016. ICCO Quarterly Bulletin of Cocoa Statistics. Vol. XLII. No. 1 Cocoa year 2015/16.

Kadariah 1988. Evaluasi Proyek (Analisa Ekonomis). Edisi Dua. Lembaga Penerbit Fakultas Ekonomi Universitas Indonesia. Jakarta.

MewaAriani, Andi Askin dan Juni Hestina, 2003. Analisis Daya Saing Usatani Tebu di Provinsi Jawa Timur. Pusat Penelitian dan Pengembangan Sosial Ekonomi Pertanian. Departemen Pertanian. Bogor.

Monke, E.A and S.R Pearson. 1989. The Policy Anayisis Matrix for Agriculture Development. Cornell University Press. Ithaca.

Nash, CA dan Pearce, DW. 1981. The Social Appraisal of Project. The Mac Millan Press. London.

Wahyudi, A., 1989. Analisis Keunggulan Komparatif Usahatani Lada Hitam Lampung dan Lada Putih Muntok Dengan Usahatani Karet, Kopi dan Kakao. Tesis Pasca Sarjana. Fakultas Pasca Sarjana. Institut Pertanian Bogor (tidak dipublikasikan). 124 hal. 